\title{
Pemanfaatan Air Larutan Garam Sebagai Kabel Penghantar Listrik Pengganti Tembaga
}

\author{
Muhammad Adhzerian Syafitra Rezki ${ }^{1}$, Harri Maliansyah ${ }^{2}$, Dimas Yusuf Ariyanto ${ }^{3}$, \\ Muhammad Faishal ${ }^{4}$ \\ ${ }^{1}$ Program Studi Teknik Elektro Universitas Ahmad Dahlan, Yogyakarta, Indonesia \\ 2,3,4 Program Studi Teknik Industri Universitas Ahmad Dahlan, Yogyakarta, Indonesia
}

\section{INFORMASI ARTIKEL}

Riwayat Artikel:

Dikirimkan 22 Juli 2019, Direvisi 10 Agustus 2019, Diterima 04 September 2019.

\section{Kata Kunci:}

Air Larutan Garam,

Kabel Listrik,

Penghantar Listrik.

\section{Penulis Korespondensi:}

M. Adhzerian Syafitra Rezki Program Studi Teknik Elektro, Universitas Ahmad Dahlan, Yogyakarta, Indonesia.

Surel:

\begin{abstract}
ABSTRAK
Penelitian ini bertujuan memanfaatkan air larutan garam sebagai penghantar listrik untuk menjadikannya alternatif pengganti kabel tembaga yang saat ini banyak digunakan dalam menghantarkan listrik. Proses dari air larutan garam yang dapat menghantarkan listrik karena pada larutan garam menggandung $\mathrm{NaCl}$ yang mengakibat adanya perpindahan elektron dari suatu atom ke atom yang lain. Dalam penelitian ini menggunakan beberapa sampel massa garam yang berbeda-beda serta dilakukan perbandingan daya hantar listrik dengan air tanpa larutan garam dan tembaga yang dihubungkan pada beban lampu sebesar 10 Watt. Hasil pengujian yang didapatkan, larutan tanpa garam menghasilkan daya sebesar 0,94 Watt dan larutan dengan massa garam 50 gram, 100 gram, 200 gram dan 400 gram menghantarkan daya listrik sebesar 3,43 Watt, 4,51 Watt, 6,17 Watt dan 7,61 Watt sedangkan daya hantar tembaga sebesar 9,51 Watt. Hal tersebut menunjukkan bahwa dalam penggunaan air larutan garam sebagai penghantar listrik, jika semakin bertambah massa garam maka daya hantar listrik yang dihasilkan juga akan semakin besar.
\end{abstract}

This study aims to use salt water as an electrical conductor to make it an alternative to copper wires which are currently widely used in conducting electricity. The process of saltwater solution that can conduct electricity because the salt solution contains $\mathrm{NaCl}$ which results in the transfer of electrons from one atom to another. In this study using several different samples of the mass of salt and comparing the conductivity of electricity with water without salt and copper solutions connected to the lamp load of 10 Watts. The test results obtained, a solution without salt produces power of 0.94 Watt and a solution with a mass of salt 50 grams, 100 grams, 200 grams and 400 grams deliver electrical power of 3.43 Watts, 4.51 Watts, 6.17 Watts and 7.61 Watts while the conductivity of copper is 9.51 Watt. This shows that in the use of saltwater as a conductor of electricity if the mass of salt increases, the conductivity of electricity produced will also be even greater.

This work is licensed under a Creative Commons Attribution-Share Alike 4.0

\section{Sitasi Dokumen ini:}

M. A. S. Rezki, H. Maliansyah, D. Y. Ariyanto, M. Faishal, "Pemanfaatan Air Larutan Garam Sebagai Kabel Penghantar Listrik Pengganti Tembaga," Buletin Ilmiah Sarjana Teknik Elektro, vol. 1, no. 2, pp. 64--72, 2019. DOI: $10.12928 /$ biste.v1i2.884

\section{PENDAHULUAN}

Seiring berkembangnya teknologi pada era saat ini menjadikan kebutuhan serta penggunaan energi listrik sangat dibutuhkan, seperti halnya dengan kehidupan rumah tangga masyarakat. Listrik saat ini menjadi salah satu kebutuhan masyarakat yang sangat penting serta menjadi sumber daya yang paling utama dibutuhkan dalam berbagai proses kegiatan. Berdasarkan data dari Kementerian Energi dan Sumber Daya Mineral (ESDM) pada Tahun 2019, rasio elektrifikasi telah mencapai 98,81\%. Jika pada tahun 2018 rumah tangga berlistrik berjumlah 66.921.705, hingga akhir Juni 2019 jumlahnya menjadi 67.548 .773 atau mengalami penambahan sebanyak 627.068 rumah tangga [1]. Penggunaan listrik saat ini masih banyak menggunakan kabel tembaga sebagai perantara untuk menghantarkan listrik yang di distribusikan oleh PLN yang kemudian dipergunakan dalam kehidupan masyarakat seperti untuk memenuhi kebutuhan penerangan rumah tangga. 
Garam adalah senyawa ionik yang terdiri dari ion positif (kation) dan ion negatif (anion), sehingga membentuk senyawa netral (tanpa bermuatan). Kation garam dapat dianggap berasal dari suatu basa, sedangkan anionnya berasal dari suatu asam oleh karenanya garam terbentuk dari hasil reaksi asam dan basa. Larutan garam dalam air merupakan larutan elektrolit, yaitu larutan yang dapat menghantarkan arus listrik [2]. Salinitas merupakan kadar garam yang terlarut dalam air. Salinitas juga merupakan bagian dari sifat fisik kimia suatu perairan selain suhu, PH, substrat dan lain-lain [3].

Penelitian tentang larutan dalam air dari beberapa zat yang dapat menghantarkan listrik disebut elektrolit. Tidak semua zat yang terlarutkan dapat menghantarkan listrik yang disebut dengan non elektrolit. Partikel dalam larutan yang menghantarkan listrik merupakan ion-ion. Ion-ion inilah yang menentukan sifat hantaran listrik serta sifat fisika dan kimia suatu elektrolit. Elektrolit pada umumnya berbentuk asam dan basa atau garam. Ada beberapa gas juga dapat digunakan sebagai elektrolit dengan kondisi tertentu misalnya pada suhu tinggi atau tekanan rendah. Ion dari garam $\mathrm{NaCl}$ menghasilkan reaksi anode dan katode, ion negatif dari garam akan mengoksidasi $\mathrm{Pb}$ elektrode yang mengakibatkan adanya perbedaan potensial antara elektrode $\mathrm{Pb}$ dan menyebabkan arus listrik [4].

Penghantar saat ini berupa seutas kawat atau kabel baik telanjang maupun berisolasi yang dapat menghantarkan arus listrik. Penghantar terdiri dari dua jenis yaitu kabel yang merupakan penghantar dengan dilapisi bahan isolasi dan kawat sebagai penghantar tanpa dilapisi isolasi [5]. Bahan isolasi adalah bahan yang digunakan untuk memisahkan dua atau lebih penghantar listrik yang memiliki tegangan listrik sehingga antara penghantar-penghantar tersebut tidak terjadi lompatan listrik atau percikan [6].

Pada penelitian yang telah dilakukan oleh Lissa dan Abdul tentang perbandingan tegangan yang diberi larutan garam untuk menggerakkan kipas angin sederhana, berdasarkan hasil pengujian dengan massa garam yang berbeda didapatkan besar tegangan berbanding lurus terhadap pertambahan massa garam. Hal tersebut menandakan bahwa larutan garam dengan massa yang berbeda juga berbanding lurus terhadap pergerakan kipas angin sederhana, jika semakin besar massa garam maka pergerakan kipas angin semakin kuat [7].

Daya hantar listrik pada larutan adalah ukuran seberapa kuat suatu larutan dalam menghantarkan listrik. Daya hantar listrik merupakan kebalikan dari hambatan listrik (R) dengan

$$
R=\rho \frac{\ell}{A}
$$

Nila hambatan dinyatakan dalam $\operatorname{Ohm}(\Omega)$, Sementara daya hantar listrik dinyatakan

dengan: $\mathrm{k}=1 / \mathrm{R}$

$$
D H L=k \frac{A}{\ell}
$$

Daya hantar listrik disebut juga dengan konduktivitas yaitu merupakan ukuran seberapa kuat suatu larutan dapat menghantarkan listrik. Nilai konduktivitas akan semakin besar jika jumlah ion suatu larutan juga semakin besar. Oleh karena itu, nilai konduktivitas larutan sebanding dengan nilai hantar molar. Sementara konsentrasi elektrolit sangat menentukan besarnya konduktivitas molar $(\Delta \mathrm{m})$ yang dirumuskan sebagai berikut:

$$
\Delta m=\frac{k}{C}
$$

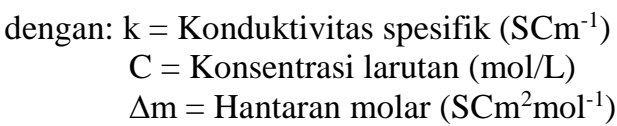

Tembaga merupakan suatu unsur kimia yang memiliki lambang $\mathrm{Cu}$. Tembaga memiliki sifat penghantar listrik dan panas yang tinggi serta sifat tahanan korosi yang sangat baik. Sehingga produksi tembaga sebagian besar dipakai sebagai kawat atau bahan untuk menghantarkan listrik. Karena sifat tembaga yang mudah menghantarkan listrik penggunaan tembaga terbesar digunakan untuk kabel listrik yakni sebesar 60\%[8]. Dengan penggunaan tembaga sebesar $60 \%$ sebagai kabel listrik yang sewaktu-waktu hasil tambang tembaga akan semakin berkurang dan habis diperlukannya metode penghantar listrik yang lain dengan biaya produksi yang relatif murah jika dibandingkan menggunakan emas ataupun perak.

\section{METODE PENELITIAN}

\subsection{Eksperimen}

Metode ini dilaksanakan di Bangunan Lab Industri Kampus 3 UAD. Percobaan dilakukan pada larutan garam dengan massa yang berbeda-beda yang dimasukkan ke dalam selang air sebagai isolasi untuk 
menghantarkan listrik yang dihubungkan pada beban lampu 10 watt. Percobaan ini dilakukan dengan urutan sampel sebagai berikut:

1. Larutan garam dengan berbagai massa

2. Larutan tanpa garam

3. Tembaga

\subsection{Perancangan Isolasi}

Pada perancangan isolasi yang digunakan berupa selang air dengan ukuran diameter 3/16 sebagai bahan isolasi larutan garam untuk menghantarkan listrik agar mudah dalam proses pembuatan dan pengambilan data uji coba. Desain perancangan isolasi dapat dilihat pada Gambar 1.

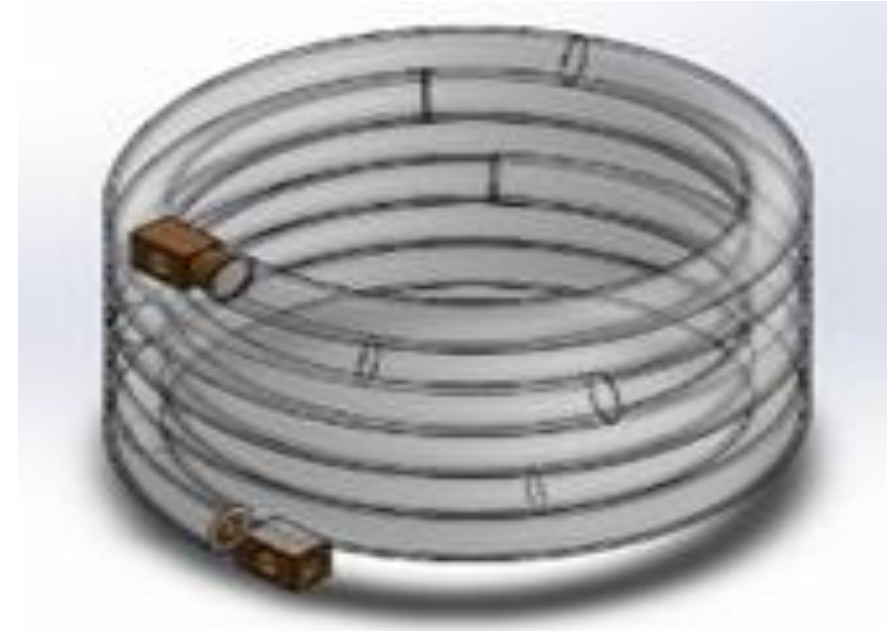

Gambar 1. Desain isolasi

\subsection{Persiapan Alat dan Bahan}

\subsubsection{Alat}

Penggunaan berbagai macam alat penelitian guna tercapainya suatu hasil penelitian yang nyata. Berikut adalah alat yang digunakan:

1. Multimeter analog/digital

2. Gelas ukur

3. Saringan halus

4. Timbangan digital mini

\subsubsection{Bahan}

Bahan penelitian yang akan digunakan pada penelitian sesuai dengan kebutuhan sebagai berikut:

1. Garam

2. Air secukupnya

3. Beban lampu LED 10 Watt

4. Selang air diameter $3 / 16$ sepanjang 10 meter

5. Kabel listrik tembaga sepanjang 5 meter

6. Fiting lampu

7. Steker

\subsection{Prosedur Pengerjaan}

Ada pun proses pengerjaan yang akan dilakukan sebelum proses pengujian dengan melakukan beberapa tahap sebagai berikut:

\subsubsection{Pembuatan Larutan Garam}

Sebagai bahan uji coba yang akan diteliti dalam menghantarkan listrik, proses pembuatan larutan melalui tahapan berikut:

1. Mengambil sampel massa garam dan diukur massanya menggunakan timbangan digital

2. Melarutkan dengan volume air yang sama pada gelas ukur

3. Melakukan penyaringan pada air larutan garam 


\subsubsection{Memasukkan Larutan Garam ke dalam Selang}

Larutan garam yang telah dilakukan penyaringan dengan berbagai macam massa kemudian dimasukkan ke dalam selang air dan kedua ujung selang diberi besi seperti pada Gambar 1 agar larutan garam tidak keluar. Dengan catatan setelah melakukan pengujian selang dicuci dan dimasukkan kembali dengan sampel larutan garam yang massanya berbeda.

\subsection{Pengujian}

Adapun pengujian yang dilakukan meliputi prosedur pengujian sebagai berikut:

1. Mengukur tegangan sumber listrik PLN

2. Mengukur tegangan keluaran dari larutan garam dan tanpa larutan garam

3. Mengukur arus yang mengalir melalui larutan garam, tanpa larutan garam dan tembaga

4. Menghitung daya hantar listrik larutan garam yang dihubungkan pada beban lampu $10 \mathrm{Watt}$

5. Membuat perbandingan daya hantar listrik yang dihasilkan larutan garam, larutan tanpa garam dan tembaga

Sementara diagram alir penelitian ditunjukkan pada Gambar 2. Penelitian dimulai dari studi literatur yang bertujuan untuk mencari referensi yang memperdalam pengetahuan tentang topik penelitian. Kemudian dilanjutkan dengan mendesain alat, mengumpulkan bahan, pembuatan alat, pembuatan sampel sebanyak 4 buah, pengujian alat dan tahap terakhir adalah analisis.

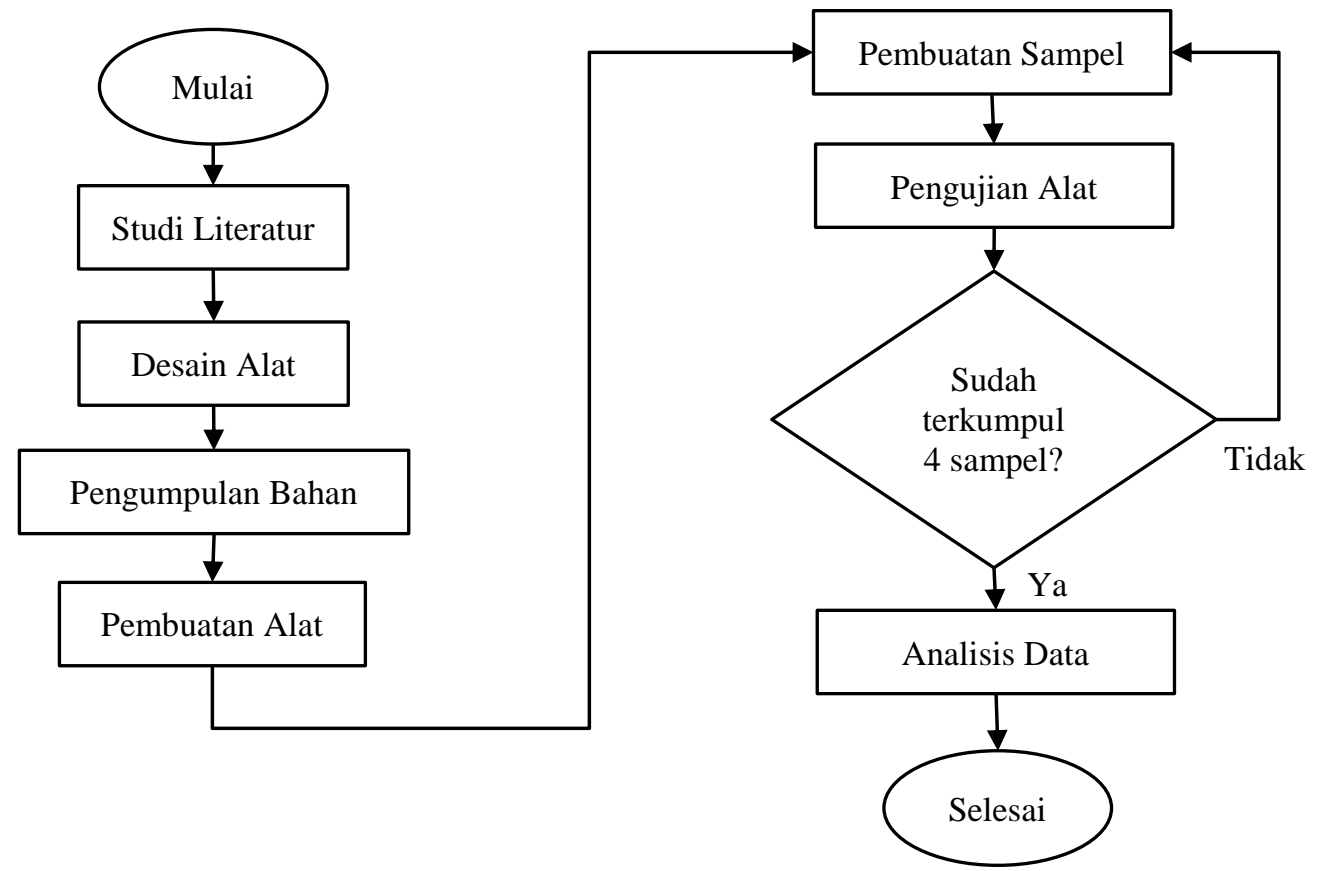

Gambar 2. Diagram Alir penelitian

\subsection{Analisis Data}

Metode ini bertujuan untuk mencatat hasil pengujian pada masing-masing sampel larutan garam terutama tegangan arus dan daya hantar listrik yang mengalir pada beban lampus 10 Watt dengan larutan tanpa garam dan tembaga sebagai pembanding hasil pengujian, sehingga dari data tersebut dapat diolah menjadi bentuk grafik. Data-data yang diperoleh akan dianalisis dengan menggunakan grafik sehingga hubungan antara besaran-besaran yang didapatkan dari hasil pengujian pada larutan garam dan pembandingnya dapat terlihat agar diambil suatu kesimpulan yang nyata.

\section{HASIL DAN PEMBAHASAN}

Pada bagian ini terdapat beberapa pengujian yaitu pengukuran tegangan sumber PLC, pengukuran nilai arus dan pengukuran daya hantar listrik. Pengujian terakhir adalah pengujian menyalakan lampu dengan kabel tembaga, kabel larutan garam, dan kabel tanpa larutan garam (air murni).

\subsection{Hasil Pengukuran Tegangan Sumber PLN pada Larutan Garam}

Setelah dilakukannya pengujian untuk mengukur tegangan sumber dan tegangan keluaran pada larutan garam dengan menggunakan volume air yang sama dan 4 massa garam yang berbeda serta larutan tanpa garam 
sebagai pembanding keluaran tegangan. Pengujian ini bertujuan untuk mengetahui pengaruh konsentrasi garam pada larutan dalam menghasilkan tegangan. Hasil pengujian pengukuran tegangan dapat dilihat pada Tabel 3.1.

Berdasarkan pada Tabel 3.1 dapat diketahui bahwa semakin besar nilai massa garam, semakin besar nilai tegangan yang dihantarkan. Oleh karena itu untuk dapat membuat kabel penghantar yang baik dengan menggunakan larutan garam, diperlukan campuran massa garam dengan jumlah yang banyak.

Tabel 3.1. Data pengujian pengukuran tegangan

\begin{tabular}{ccccccc}
\hline \multirow{2}{*}{$\begin{array}{c}\text { Waktu } \\
\text { (Detik) }\end{array}$} & $\begin{array}{c}\text { Sumber } \\
\text { PLN } \\
(\text { Volt })\end{array}$ & $\begin{array}{c}\text { Garam } \\
50 \\
(\mathrm{gram})\end{array}$ & $\begin{array}{c}\text { Garam } \\
100 \\
(\mathrm{gram})\end{array}$ & $\begin{array}{c}\text { Garam } \\
200 \\
(\mathrm{gram})\end{array}$ & $\begin{array}{c}\text { Garam } \\
400 \\
(\mathrm{gram})\end{array}$ & $\begin{array}{c}\text { Tanpa } \\
\text { Garam }\end{array}$ \\
\hline 5 & 227,8 & 190,6 & 196,4 & 205,7 & 210,1 & 105,1 \\
\hline 10 & 227,7 & 191,1 & 196,1 & 206,2 & 209,8 & 105,4 \\
\hline 15 & 228,3 & 191,2 & 196,2 & 206 & 209,7 & 105,3 \\
\hline 20 & 228 & 190,7 & 196 & 206,3 & 210,3 & 105 \\
\hline 25 & 227,7 & 190,7 & 196,3 & 206,1 & 209,9 & 105,2 \\
\hline 30 & 227,8 & 191 & 196,5 & 205,9 & 209,7 & 105,1 \\
\hline 35 & 228,4 & 190,8 & 196,2 & 205,8 & 210 & 105 \\
\hline 40 & 228,3 & 191,1 & 196,1 & 206 & 210,3 & 105,3 \\
\hline 45 & 228 & 190,9 & 196,4 & 206,2 & 210,1 & 105,4 \\
\hline 50 & 227,9 & 191,2 & 196 & 206,3 & 209,7 & 105,3 \\
\hline 55 & 228,1 & 191 & 196,3 & 206 & 209,9 & 105,1 \\
\hline 60 & 227,8 & 191,1 & 196,2 & 206,1 & 210 & 105,1 \\
\hline
\end{tabular}

\subsection{Hasil Pengukuran Arus yang Mengalur Melalui Larutan Garam, Tanpa Garam dan Tembaga}

Pada pengujian pengukuran arus dilakukan sama seperti pada pengujian sebelumnya dengan larutan tanpa garam dan tembaga sebagai pembanding. Pengujian ini bertujuan untuk mengetahui besarnya arus yang dihasilkan. Hasil pengujian pengukuran arus dapat dilihat pada Tabel 3.2.

Tabel 3.2. Data pengujian pengukuran arus

\begin{tabular}{ccccccc}
\hline \multirow{2}{*}{$\begin{array}{c}\text { Waktu } \\
\text { (Detik) }\end{array}$} & Tembaga & $\begin{array}{c}\text { Garam } \\
50 \\
(\mathrm{gram})\end{array}$ & $\begin{array}{c}\text { Garam } \\
100 \\
(\mathrm{gram})\end{array}$ & $\begin{array}{c}\text { Garam } \\
200 \\
(\mathrm{gram})\end{array}$ & $\begin{array}{c}\text { Garam } \\
400 \\
(\mathrm{gram})\end{array}$ & $\begin{array}{c}\text { Tanpa } \\
\text { Garam }\end{array}$ \\
\hline 5 & 0,043 & 0,018 & 0,023 & 0,031 & 0,036 & 0,009 \\
\hline 10 & 0,044 & 0,019 & 0,024 & 0,03 & 0,037 & 0,008 \\
\hline 15 & 0,044 & 0,016 & 0,022 & 0,029 & 0,033 & 0,009 \\
\hline 20 & 0,041 & 0,016 & 0,023 & 0,031 & 0,035 & 0,007 \\
\hline 25 & 0,042 & 0,017 & 0,023 & 0,028 & 0,037 & 0,009 \\
\hline 30 & 0,041 & 0,019 & 0,021 & 0,03 & 0,034 & 0,008 \\
\hline 35 & 0,044 & 0,018 & 0,022 & 0,03 & 0,033 & 0,006 \\
\hline 40 & 0,042 & 0,018 & 0,024 & 0,029 & 0,035 & 0,009 \\
\hline 45 & 0,043 & 0,016 & 0,024 & 0,031 & 0,036 & 0,009 \\
\hline 50 & 0,041 & 0,019 & 0,022 & 0,028 & 0,033 & 0,007 \\
\hline 55 & 0,044 & 0,017 & 0,023 & 0,028 & 0,033 & 0,006 \\
\hline 60 & 0,042 & 0,017 & 0,021 & 0,029 & 0,034 & 0,006 \\
\hline
\end{tabular}

Berdasarkan pada Tabel 3.2 dapat diketahui bahwa semakin besar massa garam, semakin besar pula nilai Arus yang dihasilkan.

\subsection{Daya Hantar Listrik Larutan Garam}

Dengan menghitung daya yang dihasilkan berdasarkan hasil pengujian pengukuran tegangan dan arus yang mengalir dengan dihubungkan beban lampu 10W. Pengujian ini bertujuan untuk melihat hasil dari nyala lampu yang dihantarkan menggunakan larutan garam, tanpa larutan garam serta tembaga. Pada Tabel 3.3 menunjukkan hasil dari daya hantar listrik larutan garam, tanpa garam dan tembaga. 
Berdasarkan pada Tabel 3.3 dapat diketahui bahwa semakin besar massa garam dalam larutan garam, semakin besar pula nilai Daya hantar listrik yang dihasilkan. Hal tersebut disebabkan karena semakin besar massa garam, semakin besar juga nilai arus dan tegangan yang dihantarkan.

Tabel 3.3. Data perhitungan daya hantar listrik

\begin{tabular}{ccccccc}
\hline \multirow{2}{*}{$\begin{array}{c}\text { Waktu } \\
\text { (Detik) }\end{array}$} & Tembaga & $\begin{array}{c}\text { Garam } \\
50 \\
(\mathrm{gram})\end{array}$ & $\begin{array}{c}\text { Garam } \\
100 \\
(\mathrm{gram})\end{array}$ & $\begin{array}{c}\text { Garam } \\
200 \\
(\mathrm{gram})\end{array}$ & $\begin{array}{c}\text { Garam } \\
400 \\
(\mathrm{gram})\end{array}$ & $\begin{array}{c}\text { Tanpa } \\
\text { Garam }\end{array}$ \\
\hline 5 & 9,7954 & 3,4308 & 4,5172 & 6,3767 & 7,5636 & 0,9459 \\
\hline 10 & 9,5634 & 3,6309 & 4,7064 & 6,186 & 7,7626 & 0,8432 \\
\hline 15 & 9,3603 & 3,0592 & 4,3164 & 5,974 & 6,9201 & 0,9477 \\
\hline 20 & 9,12 & 3,0512 & 4,508 & 6,3953 & 7,3605 & 0,735 \\
\hline 25 & 9,5634 & 3,2419 & 4,5149 & 5,7708 & 7,7663 & 0,9468 \\
\hline 30 & 9,3398 & 3,629 & 4,1265 & 6,177 & 7,1298 & 0,8408 \\
\hline 35 & 9,5928 & 3,4344 & 4,3164 & 6,174 & 6,93 & 0,63 \\
\hline 40 & 9,5886 & 3,4398 & 4,7064 & 5,974 & 7,3605 & 0,9477 \\
\hline 45 & 9,804 & 3,0544 & 4,7136 & 6,3922 & 7,5636 & 0,9486 \\
\hline 50 & 9,3439 & 3,6328 & 4,312 & 5,7764 & 6,9201 & 0,7371 \\
\hline 55 & 9,124 & 3,247 & 4,5149 & 5,768 & 6,9267 & 0,6306 \\
\hline 60 & 9,5676 & 3,2487 & 4,1202 & 5,9769 & 7,14 & 0,6306 \\
\hline
\end{tabular}

\subsection{Grafik Perbandingan Tegangan}

Grafik nilai tegangan dengan konsentrasi larutan garam yang berbeda, ditunjukkan pada Gambar 2. Pada gambar tersebut sumbu $\mathrm{x}$ adalah nilai waktu dan sumbu y adalah nilai tegangan yang dihantarkan.

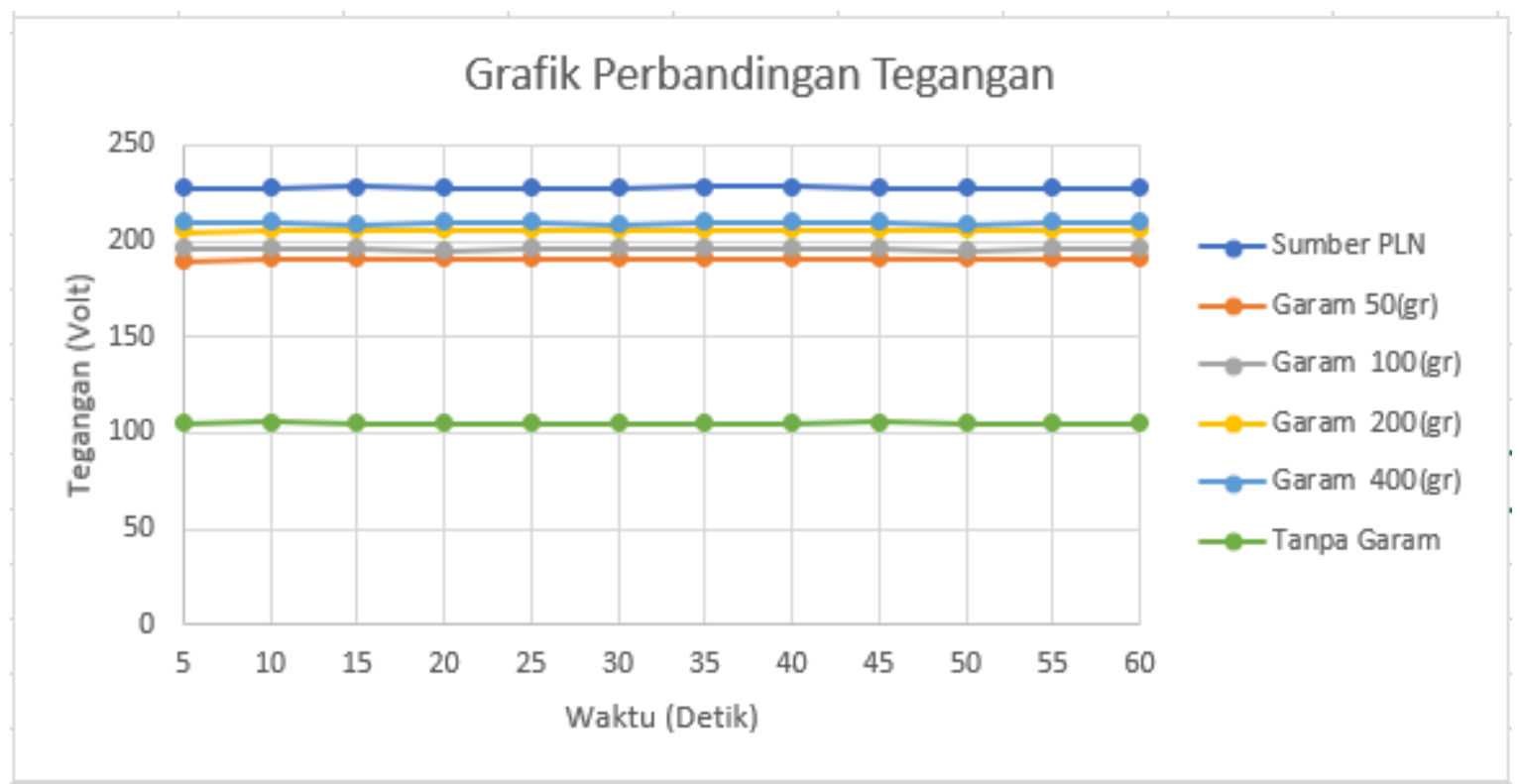

Gambar 2. Perbandingan tegangan sumber PLN, larutan garam dan tanpa garam

Berdasarkan grafik hasil pengujian tegangan pada Gambar 2 terlihat bahwa massa garam mempengaruhi keluaran tegangan dengan bertambahnya massa garam besar tegangan keluaran juga akan bertambah besar. Ini menjelaskan bahwa konsentrasi massa garam berbanding lurus dengan besar tegangan keluaran yang dihasilkan sedangkan pada larutan tanpa garam tegangan yang dihasilkan paling rendah. Sementara larutan garam 400gram memiliki nilai tegangan paling besar.

\subsection{Grafik Perbandingan Arus}

Grafik nilai pembacaan arus konsentrasi larutan garam yang berbeda, ditunjukkan pada Gambar 3. Pada

Gambar 3 sumbu x adalah nilai waktu dan sumbu y adalah nilai arus yang dihasilkan. 


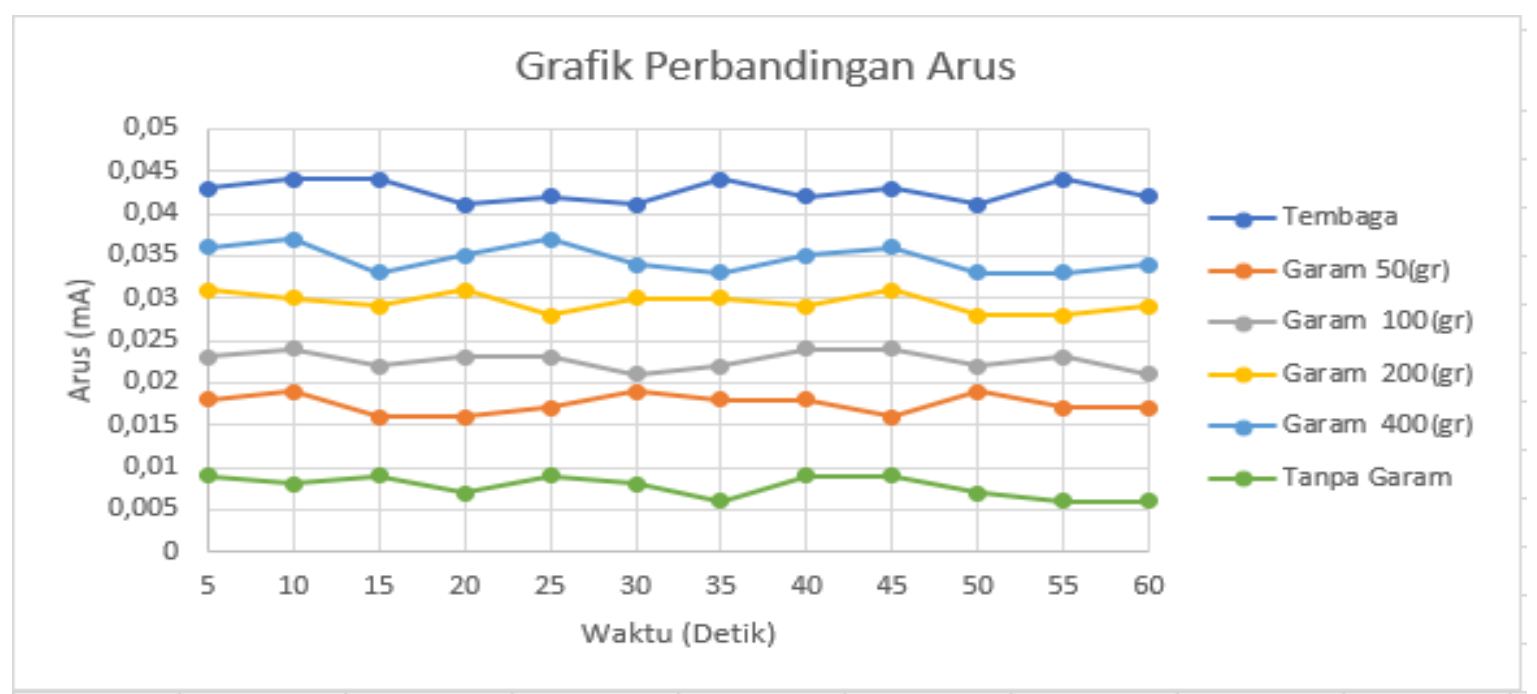

Gambar 3. Perbandingan arus yang mengalir melalui larutan garam, tanpa garam dan tembaga

Berdasarkan grafik hasil pengujian arus pada Gambar 3 terlihat hasil arus yang melalui larutan garam sama seperti pengujian sebelumnya yakni penambahan massa garam berbanding lurus dengan arus yang dihasilkan. Pada larutan tanpa garam arus yang dihasilkan memiliki nilai paling rendah sementara larutan garam 400gram memiliki nilai arus paling besar.

\subsection{Grafik Daya Hantar Listrik}

Hasil grafik pembacaan nilai daya hantar listrik ditunjukkan pada Gambar 4. Pada gambar tersebut sumbu $\mathrm{x}$ adalah nilai daya hantar listrik dan sumbu y adalah nilai waktu.

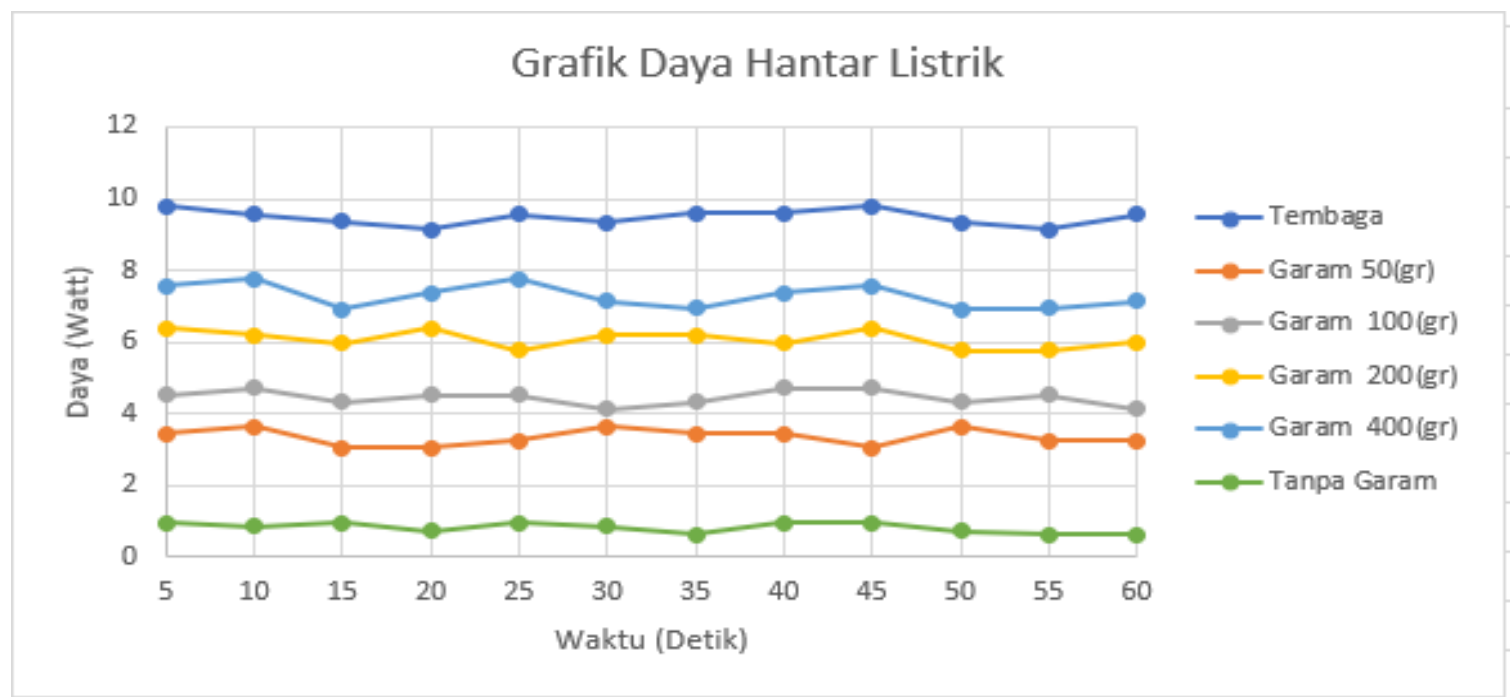

Gambar 4. Daya hantar listrik yang dihasilkan dari larutan garam, tanpa garam dan tembaga

Berdasarkan grafik perhitungan daya hantar listrik dengan menggunakan persamaan (2) yang dihasilkan dari larutan garam, larutan tanpa garam dan tembaga, hasil pengujian yang dihubungkan dengan beban lampu 10 Watt dapat dilihat pada Gambar 5. 


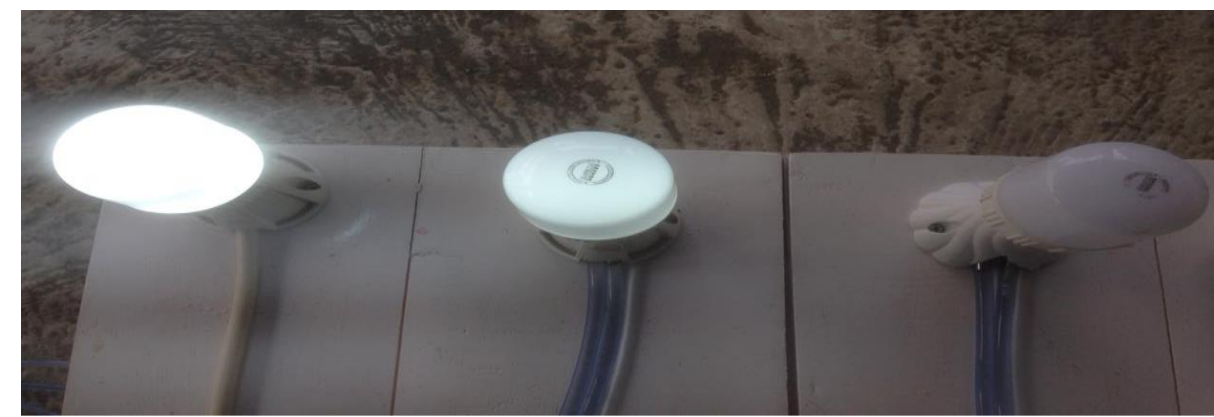

Gambar 5. Nyala lampu 10 Watt dengan urutan (kiri) kabel tembaga, (tengah) kabel larutan garam 400gram dan (kanan) kabel tanpa larutan garam

Berdasarkan pada Gambar 5 nyala lampu pada larutan garam (tengah) masih redup dikarenakan arus yang mengalir kecil jika dibandingkan dengan tembaga (kiri). Sementara pada larutan tanpa garam (kanan) lampu tidak menyala.

\section{KESIMPULAN}

Dari data-data hasil pengujian dapat disimpulkan bahwa massa garam berbanding lurus terhadap tegangan dan arus, semakin banyak massa garam yang dilarutkan maka tegangan keluaran yang dihasilkan serta arus yang mengalir pada larutan juga akan bertambah besar. Dengan perbandingan menggunakan larutan tanpa garam dan tembaga hasil daya hantar listrik pada beban lampu 10 Watt bahwa larutan tanpa garam menghasilkan daya yang sangat kecil yaitu 0,94 Watt dan larutan dengan massa garam 50 gram, 100 gram, 200 gram dam 400 gram menghantarkan daya listrik sebesar 3,43 Watt, 4,51 Watt, 6,17 Watt dan 7,61 Watt sedangkan daya hantar tembaga sebesar 9,51 Watt. Berdasarkan hasil pengujian yang telah dilakukan, ini menunjukkan penggunaan air larutan garam sebagai penghantar listrik diperoleh hasil yang signifikan yaitu peningkatan daya hantar listrik sebanding dengan jumlah massa garam dalam larutan.

\section{REFERENSI}

[1] "Terus Dikebut, Rasio Elektrifikasi Kini Capai 98,81\%," Kementerian Energi dan Sumber Daya Mineral, 2019. Online

[2] J. Saintika, M. Mungkin, and T. Ikhsan, "NaCl + Na-EDTA sebagai Elektrolit Baterai," Journal of Electrical Technology., vol. 3, no. 1, pp. 34-39, 2018. Online

[3] I. Himmaty and Endarko, "Pembuatan Elektroda Dan Perancangan Sistem Capacitive Deionization Untuk Mengurangi Kadar Garam Pada Larutan Sodium Clorida (NaCl),” Berk. Fis., vol. 16, no. 3, pp. 67-74, 2013. Online

[4] S. Fariya and S. Rejeki, "Seacell (Sea Water Electrochemical Cell) Pemanfaatan Elektrolit Air Laut Menjadi Cadangan Sumber Energi Listrik Terbarukan Sebagai Penerangan Pada Sampan,” J. Sain dan Teknol., vol. 10, no. 1, pp. 44-58, 2015. DOI: 10.13140/RG.2.1.4157.4006

[5] M. H. Ali, "Studi Kelayakan Instalasi Penerangan Rumah Di Atas Umur 15 Tahun Terhadap Puil 2000 Di Desa Pancur Kecamatan Pancur Kabupaten Rembang," vol. 5, no. 1, pp. 49-57, 2013. Online

[6] G. Firmansyah, T. Haryono, and B. Sugiyantoro, "Karakteristik berbagai jenis bahan isolasi kabel instalasi tegangan rendah," J. Penel. Tek. El. dan Teknol Informasi., vol. 1, no. 3, pp. 122-127, 2014. Online

[7] L. Zikriana and A. Hamid, "Perbandingan Tegangan Yang Diberi Larutan Garam Dengan Massa Yang Berbeda Untuk Menggerakkan Kipas Angin Sederhana," Pros. Semin. Nas. MIPA III, pp. 459-463, 2017. Online

[8] A. Amiruddin and F. A. Lubis, "Analisa Pengujian Lelah Material Tembaga Dengan Menggunakan Rotary Bending Fatigue Machine,” J. Ilm. “MEKANIK” Tek. Mesin ITM, vol. 4, no. 2, pp. 93-99, 2018. Online

[9] A. Wiono and E. Rahmawati, "Perancangan Dan Pembuatan Alat Ukur Konduktivitas Larutan Berbasis Mikrokontroler," Inov. Fis. Indones., vol. 3, no. 02, pp. 7-10, 2014. Online

[10] N. Ulfia, G. Samudro, and S. Sumiyati, "Pengaruh Konsentrasi Chemical Oxygen Demand (COD) dan Larutan Garam Dalam Jembatan Garam Terhadap Kinerja Dual Chamber Microbial Fuel Cells (DCMFCs)," E-Jurnal Tek. Lingkung., vol. 4, no. 2, pp. 1-7, 2015. Online

[11] W. Handajadi, "Peningkatan Kualitas Daya Listrik Dalam Pemakaian Luminer Menggunakan Lampu Hemat Energi (LHE),” J. Teknol., vol. 7, no. 2, pp. 134-141, 2014. Online

[12] Y. P. Tanjung, S. Sentinuwo, and A. Jacobus, "Penentuan Daya Listrik Rumah Tangga Menggunakan Metode Decision Tree," J. Tek. Inform. Univ. Sam Ratulangi, vol. 9, no. 1, pp. 1-7, 2016. 
DOI: $10.35793 /$ jti.9.1.2016.14141

[13] H. D. WIrosobo and S. Rochim, “SAW-GEN' Sebagai Sumber Energi Listrik Ramah Lingkungan dan Murah," Pros. SNST 5, vol. 1, no. 1, pp. 13-17, 2014. Online

[14] A. Pratiwi, B. Yusuf, and R. Gunawan, "Analisis Perubahan Kadar Logam Tembaga (Cu) Pada Penambahan Ion Perak (Ag) Dengan Metode Elektrokoagulasi," J. Kim. Mulawarman, vol. 13, no. 1, pp. 1-3, 2015. Online

[15] S. Zaenab, N. Haq, E. Kurniawan, and M. Ramdhani, "Analisis Pembangkit Elektrik Menggunakan Media Air Garam Sebagai Larutan Elektrolit,” e-Proceeding Eng., vol. 5, no. 3, pp. 3823-3830, 2018. Online

\section{BIOGRAFI PENULIS}

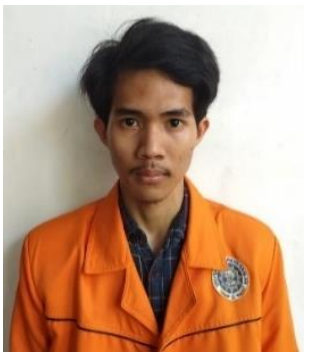

\section{Muhammad Adhzerian Syafitra Rezki}

Lahir di Jakarta, pada tanggal 03 Februari 1999. Penulis merupakan seorang mahasiswa Program Studi Teknik Elektro, Fakultas Teknologi Industri, Universitas Ahmad Dahlan. Penulis memiliki ketertarikan dalam bidang Programmable Logic Controller dan instalasi listrik.

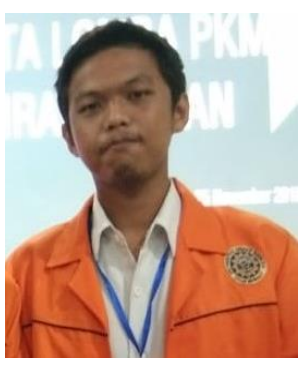

\section{Harri Maliansyah}

Lahir di Sungai Liat, pada tanggal 13 Agustus 1999. Penulis merupakan seorang mahasiswa Program Studi Teknik Industri, Fakultas Teknologi Industri, Universitas Ahmad Dahlan. Penulis memiliki ketertarikan dalam bidang menggambar teknik.

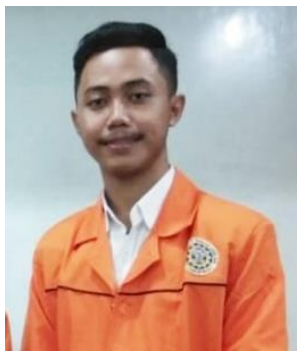

\section{Dimas Yusuf Ariyanto}

Lahir di Ngawi, pada tanggal 20 September 1999. Penulis merupakan seorang mahasiswa Program Studi Teknik Industri, Fakultas Teknologi Industri, Universitas Ahmad Dahlan. Penulis memiliki ketertarikan dalam bidang mekanika teknik dan ekonomi teknik.

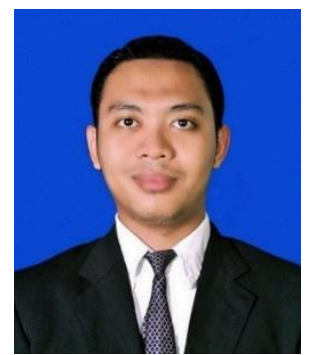

\section{Muhammad Faishal}

Lahir di Pati, pada tanggal 22 Februari 1985. Penulis merupakan seorang dosen Program Studi Teknik Industri, Fakultas Teknologi Industri, Universitas Ahmad Dahlan. 